Síntese: Revista de Filosofia adere a uma Licença Não comercial 4.0 Internacional - Creative Commons

DOI: $10.20911 / 21769389 v 48 n 151 p 297 / 2021$

\title{
artigos
}

\section{MEMÓRIA DO SER E AFIRMAÇÃO DE DEUS EM LIMA VAZ (IV) *}

\author{
Memory of the Being and affirmation of God in Lima Vaz (IV)
}

Marcelo F. de Aquino, S.J. **

Resumo: Neste quarto artigo da pesquisa que tem como tema a Memória do Ser e a Afirmação de Deus em Lima Vaz, torna-se mais clara a crítica vaziana à transformação da Metafísica do Esse de Tomás de Aquino resultante do processo de inversão do seu vetor noético-metafísico, que ocorreu a partir de Duns Scotus.

\footnotetext{
* Artigo recebido em 25/08/2019 e aprovado para publicação em 30/11/2019. Este é o quarto artigo de uma série precedentemente publicada nesta revista e que faz parte de meu Projeto de Pesquisa junto ao Programa de Pós-Graduação em Filosofia da Universidade do Vale do Rio dos Sinos - UNISINOS. As ideias e os textos do Pe. Henrique Cláudio de Lima Vaz estão íntima e profundamente assimilados pela minha pesquisa, querendo, como o quero, dar continuidade à mesma tradição filosófica. Para a bibliografia de e sobre Lima Vaz ver Ribeiro, E. V., Reconhecimento ético e virtudes. São Paulo: Loyola, 2012. Os textos fonte de pesquisa são: LIMA VAZ, H. C., Escritos de Filosofia: Problemas Fronteira, São Paulo, 1986 (EF, PF); Escritos de Filosofia II: Ética e cultura. São Paulo: Loyola, 1988 (EF II, EC); Escritos de Filosofia: Filosofia e cultura. São Paulo: Loyola, 1997 (EF III, FC); Escritos de Filosofia IV: Introdução à ética filosófica I. São Paulo: Loyola, 1999 (EF IV, IEF I); Escritos de Filosofia V: Introdução à ética filosófica II. São Paulo: Loyola, 2000 (EF V, IEF II); Escritos de Filosofia VI: Ontologia e História. São Paulo: Loyola, 2002, 2. ed; Escritos de Filosofia VII: Raízes da modernidade. São Paulo: Loyola, 2002 (EF VII: RM); Antropologia filosófica I: São Paulo: Loyola, 1991 (AF I); Antropologia Filosófica II. São Paulo: Loyola, 1992 (AF II). A publicação da edição da obra filosófica inédita de Henrique Cláudio de Lima Vaz com o objetivo de divulgar o seu pensamento através da impressão dos seus textos inéditos teve início em 2012. A edição constará de várias séries históricas e temáticas. Iniciou-se com a publicação da tese doutoral em filosofia na Pontifícia Universidade Gregoriana de Roma, com o título Contemplação e dialética nos diálogos platônicos, São Paulo: Loyola, 2012. Em 2014, inaugurando a série Manuscritos Hegelianos, foi publicada parte substancial do acervo correspondente aos cursos e outros estudos sobre Hegel intitulada A formação do pensamento de Hegel (FPH), a cargo de Arnaldo Fortes Drummond, São Paulo: Loyola, 2014.

** Prof. Dr. Marcelo Fernandes de Aquino, S. J., Reitor e Professor do Programa de Pós-Graduação em Filosofia da Universidade do Vale do Rio dos Sinos - UNISINOS. Agradeço
} 
A crítica vaziana se estende à nova arquitetônica filosófica proposta por Suarez com sua concepção de sistema metafísico. Descartes, Kant e Hegel seriam seus representantes mais reconhecidos. A semântica vaziana categoriza esse período como modernidade moderna, ou ainda modernidade pós-cristã. Autores contemporâneos preferem falar de modernidade tardia. Ao longo de aproximadamente quatro séculos e meio nova base teórica, ou novo marco referencial teórico veio sendo posto a partir do primado da representação. Trata-se da Metafísica da subjetividade, em cujo marco referencial Lima Vaz se move em sua hermenêutica cultural da pós-modernidade.

Palavras chaves: Ser. Representação. Essência. Deus. Inversão. Onto-teologia,. Mundo. Sistema.

Abstract: In this fourth research article whose themes are the Memory of Being and the Affirmation of God in Lima Vaz, the philosopher's criticism of the transformation of Aquinas's Metaphysics of Esse becomes much clearer. It results from the process of inversion of its noetic and metaphysical vector that started with Duns Scotus. Vaz's criticism extends right up to the new philosophical framework developed by Suarez and the latter's conception of a metaphysical system whose best-known representatives would be Descartes, Kant and Hegel. Lima Vaz's semantics categorizes this period as modern modernity, or even postChristian modernity. Contemporary authors prefer to speak of late modernity. Over the course of approximately four and a half centuries, a new theoretical basis, or a new theoretical framework, has been established based on the primacy of representation. It is the Metaphysics of subjectivity that provided Lima Vaz with a referential framework for his cultural hermeneutics of post-modernity.

Keywords: Being. Representation. Essence. God. Inversion. Onto-theology. World. System.

\section{O estatuto teórico do modelo antropocêntrico no pensamento tardio de Lima Vaz}

\section{Rememorando o marco referencial teórico greco-cristão}

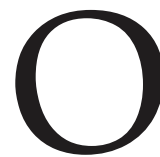

programa filosófico-sistemático tardio de Lima Vaz reflete sobre o grande evento da história intelectual do ocidente ocorrido no campo das ideias, que define novo sistema de razões e representações, ou seja, novo estilo teórico. Trata-se do advento da razão moderna, que foi precedido pelo nascimento da razão grega e pela assimilação da razão grega pela teologia cristã ${ }^{1}$. Cabe lembrar que entre os séculos III e XIII da

ao professor Carlos Alberto Gianotti, Editor-executivo da Editora UNISINOS, a leitura atenta do manuscrito e a Marlise Horn da Silva a formatação do texto.

${ }^{1}$ EF VII, RM, 11-30. 
era cristã acontece na teologia cristã a síntese, historicamente imprevisível e especulativamente paradoxal, entre Metafísica do Absoluto como Ideia, e Revelação do Absoluto como Existência ${ }^{2}$. A dialética de continuidade e descontinuidade entre mito e razão, entre filosofia antiga e teologia cristã e, finalmente, entre teologia cristã e razão moderna, que estrutura esses três eventos fundadores, é o terreno em que Lima Vaz se movimenta. A afirmação de Deus no tangenciamento da anábasis (subida) filosófica com a katábasis (descida) bíblica rememorado nos textos vazianos, sua comunicabilidade filosófico-teológica, acontece em cinco planos: o noético-metafísico, o noético-ontológico, o noético-epistemológico, o antropológico-teleológico e o ético-político.

No plano noético-metafísico, ele percorre o itinerário ${ }^{3}$ da inteligibilidade da noção de ser, primum cognitum, que implica a afirmação do Absoluto transcendente. Seu horizonte de sentido decorre da abertura estrutural e universal (=transcendental $\left.{ }^{4}\right)$ da razão à inteligibilidade do ser (sua identidade dialética com o ser), e de sua reflexividade ${ }^{5}$. Pensar a identidade do primum ontologicum e do primum logicum como Ser Absoluto é a tarefa metafísica por excelência nas várias etapas do programa filosófico vaziano. No plano noético-ontológico, a afirmação de Deus por Lima Vaz percorre o caminho da inteligibilidade intrínseca à relação transcendental do ser finito com a inteligência e liberdade do ser infinito. Participação e analogia são as categorias que regem a articulação dessa relação ${ }^{6}$. No plano noético-epistemológico, o princípio platônico-aristotélico intellectus in actu est intellectum in actu (a identidade intencional entre o intelecto em ato e o inteligível em ato) oferece a estrutura do conhecimento do ser. Nela estão em jogo: nossa concepção de inteligência, de realidade, e o tipo de relação teórica, prática e poiética que estabelecemos com essa. No plano antropológico-teleológico, o sujeito do ato praxiológico é capacidade de ser portador de si mesmo no seu movimento de autorrealização ${ }^{7}$. No plano ético-político, Lima Vaz reconceitualiza a práxis em seu núcleo inteligível antropo-teleológico expresso na dialética mensurante-mensurado. A originalidade da teleologia da práxis no seu pensamento reside na autodeterminação do sujeito agente em vista de um fim. A escritura filosófico-teológica

\footnotetext{
${ }^{2}$ Para Lima Vaz deve-se a Tomás de Aquino a única síntese conhecida entre a participação platônica, o substancialismo aristotélico e o criacionismo bíblico-cristão.

${ }^{3} \mathrm{O}$ Poema de Parmênides inicia a inquirição filosófica grega do puramente inteligível. Platão no Fédon traça a rota da sua segunda navegação, levando em conta, porém, a diversidade de modelos de sua ciência. No Sofista de Platão e na Metafísica de Aristóteles com a constituição da ciência do ser a inquirição do puramente inteligível alcança seu estágio decisivo.

${ }^{4}$ Para o uso de "transcendental" por Lima Vaz ver AF II, 135, n.118.

${ }^{5}$ Cfr. Ética e razão moderna, in Síntese Nova Fase, v. 22, n. 68 (1995), 53-85, aqui 60.

${ }^{6}$ Aqui, mesmo expondo o pensamento de Lima Vaz, cabe-me dar o devido assenso àqueles autores que vêm na doutrina da analogia uma datação medieval, como é o caso no pensamento de Tomás de Aquino.

${ }^{7}$ Ver AF II, 141-174.
} 
vaziana da ideia de Deus, ou do respectivo tratado teológico-político do Absoluto como problema cultural, é parte importante da hermenêutica cultural desenvolvida pelo pensamento tardio de Lima $\mathrm{Vaz}^{8}$ aos sucedâneos do Absoluto de existência: a classe, a raça, o Estado, a libido?.

Cabe fazer algumas observações preliminares à presente pesquisa sobre a rememoração vaziana ${ }^{10}$ do marco referencial teórico greco-cristão da afirmação de Deus. Uma revolução na representação tradicional do tempo desencadeia-se no século VI a.C. quando o lógos como epistéme (razão demonstrativa) passa a ocupar lugar cada vez mais importante no universo simbólico da civilização grega. A representação do tempo submete-se aos procedimentos da razão demonstrativa ${ }^{11}$, passando a ser construída no presente da reflexão filosófica. O tempo perde seu caráter sacral que a estrutura repetitiva própria da simbólica do mito conferia-lhe. Torna-se objeto da razão. Na esteira dessa representação do tempo como uma sucessão de modos, ou de atualidades, a reflexão de Lima Vaz compreende o tempo lógico da autodiferenciação da razão, o tempo histórico das sucessivas formas de razão, e o tempo do conceito da reestruturação modal na representação do tempo.

O ciclo de modernidades decorrente da invenção da epistéme, graças à qual a razão filosófica se pergunta pelo Princípio nos segmentos temporais, resulta dessa reestruturação modal na representação do tempo, em que o tempo lógico e o tempo histórico constituem o tempo do conceito. Com outras palavras, o tempo passa a ser o lugar do conceito. O substantivo abstrato modernidade expressa a percepção e a consciência do tempo. A consciência do tempo é uma consciência moderna. É uma consciência histórica, em cujo horizonte ocorre o primeiro e mais decisivo impacto da reorganização dos símbolos fundamentais da representação do mundo.

A emersão definitiva do logos demonstrativo como instância reguladora do sistema simbólico da sociedade, a razão no seu uso teórico, explícito ou formalizado, é outro tema que vai se desenhando no pensamento vaziano. Compreende o domínio da vida pensada, das ideias propostas, discutidas, confrontadas na esfera do universo simbólico que, a partir da Grécia, adquire seu contorno e seu movimento próprios, e que denominamos mundo intelectual. Essa é uma característica do pensamento vaziano: o mundo intelectual não evolui solitário no espaço simbólico. Forma sistema e interage com outras esferas da organização social, das estruturas de poder, das condutas, das crenças.

\footnotetext{
${ }^{8}$ A esse respeito, resta por fazer um estudo do texto "Cristianismo e Utopia" in EF, I, PF, 291-302.

${ }^{9}$ Cfr. Transcendência: História e Teoria, EF III, FC 198.

${ }^{10}$ A esse propósito ver Esquecimento e memória do Ser: sobre o futuro da metafísica, in EF VII, RM 269-286.

${ }^{11}$ Cfr. Transcendência e Modernidade: o desafio das modernidades, in EF III, FC, 223-253, aqui 223-229.
} 
A este propósito, Lima Vaz recorda que Platão e Aristóteles articulam conceitualmente a noção de Ideia como forma que circunscreve a inteligibilidade do ser - dos seres - ao contorno ou à definição de sua essência. A Ideia é termo do movimento de anábasis da mente, que se dirige do sensível ao inteligível supremo. É pensada ou atingida na intuição plenificante da união da inteligência com ela como ápice de um movimento de ascensão intelectual, ou caminho para o alto, que expressa a transgressão das fronteiras do mundo ou a elevação acima do contorno mundano.

A união da inteligência e do inteligível no noûs humano é explicada diferenciadamente na epistemologia platônica e na aristotélica. Na ontologia platônica do eidos choristón (ideia separada), é explicada pela nóesis (intuição) do noetón (inteligível em ato) que subsiste como ideia separada do sensível. Na ontologia aristotélica da forma substancial, a união é explicada pelo noûs o panta poiein (atividade da inteligência) que opera no sensível apreendido pela imaginação, a atualização do inteligível em potência, nele imanente como forma ou estrutura.

A exposição vaziana retoma duas teses que regem a Metafísica da ideia, de Platão a Descartes. A primeira defende a insuficiência do aístheton (sensível) para satisfazer a todas as exigências de explicação do noetón (inteligível). A segunda defende a prioridade ontológica, enquanto fonte de explicação, do inteligível sobre o sensível. O rumo das vicissitudes histórico-teóricas da noção de ser é dado mediante a enunciação da original dicção polissêmica da noção do ser por Aristóteles: tò d'on légetai men pollachôs (o ser se diz de muitas maneiras) ${ }^{12}$. Ao campo semântico da ideia de ser vem somar-se as ideias de uno, verdade e bem.

A contemplação do Uno por Plotino transforma a ontologia grega em henologia. A tradição neoplatônica que procede de Porfírio, discípulo e biógrafo de Plotino, aprofunda a remodelação henológica da ontologia clássica. No seu comentário ao Parmênides de Platão ${ }^{13}$, ao tratar a segunda hipótese do Parmênides "se o Uno é pode ele ser e não participar da ousia"14 Porfírio propôs uma distinção entre o ser (infinitivo einai, lat. esse) e o ente (particípio ón, lat. esse), que supõe a inteligibilidade do existir. Segundo Lima Vaz, o infinitivo einai (esse) como atributo do Primeiro Princípio no neoplatonismo porfiriano expressa a presença germinal da concepção do ato puro de existir na Antiguidade tardia. A distinção real de essência e existência no ser finito, tão relevante na Metafísica de Tomás de Aquino, tem como uma de suas fontes a distinção entre esse e quod est que ocorre no tratado De Ebdomadibus de Boécio que, por sua vez, transmite à Idade Média a doutrina germinal da inteligibilidade do existir de Porfírio.

\footnotetext{
12 Cfr. Met. IV 2, 1003 a 33.

13 Alguns fragmentos desse Comentário foram encontrados em forma de palimpsesto na Biblioteca de Turim e publicados pela primeira vez em 1892.

14 Parm., 142 b 6.
} 
Elementos do médio e neoplatonismo foram integrados organicamente, no século III d.C., ao teísmo cristão por Clemente Alexandrino e Orígenes ${ }^{15}$. Uma mudança radical na estrutura da noção clássica de ser foi provocada pela ontologia trinitário-cristã. $\mathrm{O}$ advento da relação na ordem da essência, dela decorrente, põe em questão o primado da substância característico da ontologia grega. Além disso, a relação de criaturalidade entre Deus e os seres finitos modificou profundamente os termos da dialética clássica entre o Uno e o Múltiplo. Significados distintos do Princípio ou do Uno separam a noção plotiniana de processão e a noção bíblico-cristã de criação entendida como relação de dependência no existir dos seres ao seu Princípio ou do Múltiplo ao Uno. Por parte do Princípio, que não pode ser pensado segundo uma relação real ad extra, esta é uma relação não recíproca.

$\mathrm{Na}$ ordem da essência, Lima Vaz se depara com a questão da natureza da relação do esse finito à inteligência do Esse absoluto como lugar das Ideias e Primeiro Exemplar. Sua interrogação volta-se para a inteligibilidade intrínseca ou para o logos dessa relação, segundo a qual o ser finito refere-se transcendentalmente à Inteligência e à Liberdade do Esse infinito. $\mathrm{O}$ necessitarismo da essência foi o óbice maior que impediu, no pensamento antigo antes de Plotino, a formação de uma verdadeira ideia do Absoluto. A concepção plotiniana da liberdade do Uno dá início à remoção deste óbice. A reflexão vaziana volta-se para o problema da participação ${ }^{16}$ e da analogia ${ }^{17}$. A participação implica a imanência do ser absoluto nos seres relativos. A analogia postula a transcendência do ser absoluto sobre os seres relativos $^{18}$. Na síntese de ambas elaborada por Tomás de Aquino, seguida por Lima Vaz, se cruzam as tradições platônica, aristotélica, bíblico-cristã, neoplatônica, procliana e aviceniana.

Do ponto de vista histórico-conceitual, a imagem da participação respondeu, nas representações arcaicas do mundo, à necessidade de se garantir a ordem dos seres contra a ameaça do caos, distribuindo-os em escala

\footnotetext{
${ }^{15}$ Ver "Transcendência: História e Teoria" e " Transcendência e Religião: o desafio das modernidades" in EF III, FC, respectivamente 193-221 e 223-255.

${ }^{16} \mathrm{O}$ conceito de participação surge e se impõe no pensamento de Tomás de Aquino a partir do primeiro ensinamento parisiense (1256-1259), no contexto do comentário ao De Ebdomadibus de Boécio. Provavelmente data da mesma época da questão disputada sobre o Bem no De Veritate, q. 21.

${ }_{17}$ Desde os trabalhos de P. Aubenque (Le Problème de l'être chez Aristote, Paris, PUF, 1962), A. de Libera (Les sources gréco-arabes de la théorie médiévale de l'analogie de l'être. Les études philosophiques: "L'analogie" (1989), 319-345), J.-F. Courtine (Inventio Analogiae: Métaphysique et ontothéologie, Paris, Vrin, 2005) e, mais recentemente, O. Boulnois (Metafísicas rebeldes. Gênese e estruturas de uma ciência na Idade Média. São Leopoldo, Editora Unisinos, 2015), há um consenso que o conceito de analogia na obra de Aristóteles não é aplicado ao problema do ser. É um resultado da leitura da Ética a Nicômaco segundo a leitura da Ética a Nicômaco por P. Aubenque. Santo Tomás segue uma tradição antiga e medieval de longa duração, que faz da analogia a pedra angular da metafísica.

${ }^{18}$ Ver Itinerário de ontologia clássica, in EF VI, OH, 57-76. Ver também o capítulo 12 Ser e Participação de EF VII, RM, 171-191.
} 
ascendente e hierárquica para formar patamares distintos da realidade. A transposição conceptual dessa participação imaginativa deu-se na obra de Platão. Ầ representação no campo do imaginário sucede-se a transcrição ideonômica das ordens da realidade pela normatividade das Ideias. A ideia de participação está ligada imediatamente à percepção do todo quantitativo ${ }^{19}$ e das suas partes. Aplica-se proporcionalmente a todo tipo de relação em que duas realidades se comunicam segundo uma razão de prioridade de uma com respeito a outra. Para exprimir a relação entre as coisas sensíveis e as Ideias transcendentes, Platão recorre ao verbo metéchein (tomar parte em) do qual se originam os substantivos méthexis e metoché20 (participação). Introduz a ideia de méthexis na aplicação do paradigma ideonômico à relação noética e ontológica entre o sensível e o inteligível.

A ideia de participação cumpre dupla função no nível noético-ontológico a que foi elevada por Platão: a de articular o sensível e o inteligível em termos de cognoscibilidade do segundo a partir do primeiro, e a de estabelecer a diferença ontológica entre o sensível, em permanente fluir, e o inteligível, ao qual cabe propriamente a atribuição do ontôs on, ou ser verdadeiramente tal. Segundo Platão, as formas da causalidade transcendental (eficiente, exemplar e final), segundo as quais podemos pensar a pluralidade dos seres finitos na unidade do ens commune (ser enquanto ser) medeiam nosso conhecimento do Princípio.

Platão estrutura dois modelos de participação: a participação vertical e a participação horizontal. No modelo de participação vertical dos esse no Esse subsistente o topo da hierarquia ontológica abre-se para a radical transcendência do Absoluto incircunscritível pela razão conceptualizante mas pensável como Bem (Platão), como Uno (Plotino), como Verdade (Agostinho), como Esse subsistens (Tomás de Aquino). No modelo de participação horizontal os esse e o Esse são absorvidos pela universalidade unívoca do ens commune.

O advento do modelo onto-teológico (on $=$ ser, theós $=$ deus $)$ da metafísica de Duns Scotus, com a sua distinção fundamental entre Deus, o Criador, e as criaturas, seres criados, organizados em escala ascendente segundo a perfeição da sua essência, conserva o modelo de participação vertical. Contudo, induz mudança na ordem da prioridade ontológica introduzindo uma estrutura horizontal da participação que iguala o Absoluto e o relativo no ens ut ens (o ser enquanto ser), o Infinito e o finito, Deus e as criaturas na universalidade unívoca do ens commune, ou seja, na unidade do subjectum da metafísica. Com outras palavras, a univocidade do conceito de ser abarca todos os seres, incluindo-se Deus.

${ }^{19}$ Cfr. EF VII RM 172-184.

${ }^{20} \mathrm{Na}$ língua grega os termos mímesis, metálepsis, koinonia, parousía são equivalentes a metéchein. 
A estrutura transcendental da participação é constituída por duas perspectivas distintas: o Verum e o Bonum. No primeiro caso, a participação é pensada na ordem da causalidade formal: da necessidade intrínseca da essência que, como tal, participa da Ideia na Inteligência infinita. No segundo caso, é pensada na ordem da causalidade final: da livre ordenação com que o esse participa da Liberdade infinita. A noção de ens commune, compreendendo a totalidade dos seres finitos e, como tal, subjectum da metafísica, deve ser entendida segundo a dupla perspectiva de participação dos seres finitos ao Criador: participação à Verdade pela sua essência, e participação à Bondade pelo seu fim.

A Verdade e o Bem, seguindo roteiro desenhado por Tomás de Aquino e retomado por Jan Aertsen ${ }^{21}$ e Lima Vaz, constituem o arcabouço conceptual da metafísica tomásica da participação. O esse finito se desdobra como verdade e bem e, como tal, retorna participativamente à Verdade e ao Bem no Esse subsistens (Primeiro Princípio). A natureza e a criatura são os dois caminhos seguidos pelo pensamento tomásico. O primeiro é um roteiro aristotélico, e o segundo é um roteiro cristão com sensível influência neoplatônica. No roteiro da natureza, a participação aponta para a transcendência absoluta do Esse subsistente, do qual os seres na sua totalidade, reunidos na razão do ens commune, recebem o esse participado segundo a tríplice relação da causa eficiente, exemplar e final. No roteiro da criatura, a participação é fundamento da predicação analógica entre o Esse subsistente participado (Deus) e os esse participantes (criaturas).

A estrutura da predicação analógica requer que o modo de significação seja predicado, primeiramente, a partir do conhecimento sensível dos entes finitos; mas que a realidade significada se predique, primeiramente, do Esse subsistente (Deus) como Causa primeira do ens commune e sujeito primeiro das noções transcendentais ${ }^{22}$. A estrutura analógica da participação, na qual a realidade significada tem finalmente primazia sobre a forma lógica, manifesta seu teor metafísico nas duas vertentes fundamentais: a presença inclusiva do Absoluto nos seres finitos e a sua transcendência radical expressa na tríplice causalidade, eficiente, exemplar e final.

Lima Vaz atribui ao procedimento analógico a transgressão dos limites conceituais do campo da inteligibilidade metafísica traçados pela finitude da razão humana, campo semântico das ideias de ser, uno, verdade e bem. A transgressão analógica da razão finita assegura à ideia de Deus seu lugar eminente na metafísica medieval-cristã. A estrutura analógica da metafísica do esse em Tomás de Aquino estabelece um hiato ontológico entre o Absoluto e os seres finitos. O Absoluto sendo afirmado supra intellectum ${ }^{23}$

\footnotetext{
${ }^{21}$ Cfr. Jan Aertsen, Medieval Philosophy and the Transcendentals: The Case of Thomas Aquinas. Leiden/New York, Brill, 1996.

${ }^{22}$ Cfr. De Potentia, q. 7, a. 7; Summa c. Gentiles I, c. 34; Summa Theol., q. 13, aa.5, 6, 10.

${ }^{23}$ Cfr. In lib. De Causis, VI, 6, 175.
} 
permite o desdobramento do múltiplo como pluralidade de seres finitos afirmados na sua identidade próprias, mas mantidos nos vínculos da dependência causal, que assegura a unidade na pluralidade do ens commune e sua referência constitutiva ao Uno absoluto. A transcendência inobjetivável do Absoluto traduz a hyperbolé (excesso) do Ser que é absolutamente Uno e, como tal, Verdadeiro e Bom.

No plano ético-político, a suprassunção da dialética mensurante-mensurado constitui o ethos como realidade histórico-social que se apresenta como espaço propriamente humano da práxis. Na ilustração grega, a tarefa da racionalização do ethos na forma de uma ciência do agir cabia à ética. $\mathrm{O}$ indivíduo e a sociedade, submetidas ao ethos ou recebendo as lições da ética, medeiam sua práxis segundo a escala de normas e de fins cujo fundamento e justificação transcendem o teor empírico dos objetos e a contingência do agir individual. A transcendência desse fundamento nas sociedades gregas tradicionais afirmava-se na sanção religiosa e sapiencial do ethos. Nas sociedades gregas regidas pela ilustração filosófica traduzia-se na conceptualização filosófico-teológica o ethos como ética. Em Platão e Aristóteles era o bem, ou os bens, no estoicismo a natureza.

A crítica à metafísica tomásica do esse, provavelmente iniciada por Robert Kilwardby, é levada a sua expressão mais rigorosa e aparentemente definitiva por Duns Scotus. A univocidade da noção de ser, que desencadeia a construção do sistema da metafísica na modernidade, representa um primeiro e decisivo passo para o predomínio do modelo de participação horizontal, que se torna a estrutura básica do sistema simbólico da modernidade. Configura-se dessa maneira uma primeira inversão na relação de prioridade entre participação vertical e participação horizontal.

Desde um ponto de vista metafísico, um dualismo entre metafísica da univocidade do ser e teologia da criação passa a se aninhar no sistema simbólico da modernidade na qual a participação vertical tende a desaparecer, na medida em que o horizonte da imanência torna-se, na cultura moderna, o único horizonte englobante de toda a realidade. Para Lima Vaz, esse predomínio do modelo de participação horizontal será ratificado pelas formas de racionalidade que se impõem a partir do século XVII e que têm como paradigma a racionalidade matemática ${ }^{24}$. A partir da constatação dessa inversão entre participação vertical e participação horizontal, vai se delinear o programa filosófico-sistemático vaziano como hermenêutica cultural da modernidade tardia. Essa passa a ser o marco referencial teórico da afirmação de Deus por Lima Vaz. A sua busca por novo estilo teórico terá êxito?

A este propósito, na razão moderna põe-se a questão relativa ao processo de substituição da metafísica como scientia rectrix pela matemática. Tudo

${ }^{24}$ Cfr. EF VII, RM, 188-191. 
leva a crer que nova lógica inerente à própria natureza do novo tipo de razão comandará esta substituição. $O$ fato da neutralidade axiológica da razão matemática põe à cultura contemporânea dramático desafio. $O$ enorme corpo da cultura material do mundo moderno, em contínuo crescimento, formada pelo entrelaçamento de múltiplas formas de racionalidade, teóricas, práticas e técnicas, é envolvido por densa rede simbólica. O predomínio das racionalidades modernas construídas segundo o modelo de participação horizontal, e cujo padrão de racionalidade é a racionalidade matemática, implica uma reorganização da realidade na forma de modelos abstratos que, submetidos a complexos procedimentos de verificação e devidamente comprovados, passam a traduzir, numa sucessão rigorosamente homogênea de casos, determinado aspecto da realidade. As racionalidades modernas em sua contínua diferenciação consagram o triunfo da especialização e a aparente obsolescência das grandes visões sinóticas estruturadas segundo o modelo de participação vertical.

Nos últimos quatro séculos, gigantesca transformação das condições materiais da vida humana e do próprio universo objetivo decorre da indiscutível eficácia operacional desses procedimentos. Ora, o todo quantitativo é o paradigma fundamental do modelo de participação horizontal. Nele as partes são homogêneas à natureza do todo e, como tais, sempre potencialmente divisíveis. A multiplicação incessante de objetos dentro do mesmo padrão técnico é, para Lima Vaz, a forma avassaladora contemporânea do "mau infinito" de Hegel. Dois importantes fenômenos nascem do predomínio do modelo de participação horizontal. Em primeiro lugar, considerando que a razão operacional ou instrumental por si mesma é incapaz de avaliar, ordenar e hierarquizar seus próprios produtos em termos de valores autenticamente humanos, os produtos da razão operacional acabam submetidos ao valor econômico, único valor exatamente adequado à homogeneidade da participação horizontal. Em segundo lugar, a partir do próprio projeto de leitura horizontal da realidade segundo os códigos da racionalidade matemática, apareceram formas e polos de participação segundo o modelo vertical suscitadas pela inviabilidade biológica, psicológica e cultural da igualdade universal.

Essas formas estão estruturalmente ligadas ao múltiplo quantitativo ao qual devem proporcionar uma expressão teórica unificada. São elas: o Eu transcendental na filosofia, o Estado na teoria política, a Comunidade na teoria ética, o Mercado na teoria econômica. Os polos considerados por sua própria natureza, unificadores universais do múltiplo são: a Razão operacional, a Ciência, o Progresso. Lima Vaz é incisivo em sua avalição. Essas formas de participação vertical não se elevam a um nível de transcendência ontológica sobre a imanência da história, onde a participação horizontal é arrastada pelo fluxo da sucessão temporal que volta a tudo igualar no abismo sem fundo do passado. 


\section{Invertendo o vetor noético da metafísica greco-cristã}

Segundo Lima Vaz, em fins do século XIII o ocidente latino foi atravessado por uma crise intelectual que teve seu desfecho marcado por um processo de substituição arquetípica do quadro referencial teórico então vigente por outro caracterizado, por um lado, pelo retraimento da metafísica tomásica do esse e da sua estrutura analógica orientada para a transcendência do Ipsum Esse subsistens, e, por outro lado, pelo aparecimento da "nova metafísica" da univocidade do ser. Os problemas metafísicos, antropológicos e cosmológicos que se manifestam nessa crise têm sua origem nesse difícil processo de passagem de um quadro referencial teórico por outro.

Um dos resultados a que se chegou no terceiro artigo da presente pesquisa, Memória do Ser e afirmação filosófica de Deus em Lima Vaz, foi que, nos inícios do século XIV, Duns Scotus substituiu a remodelação tomásica da noética aristotélica ${ }^{25}$ pela sua teoria do esse objectivum, ser objetivo ou objeto representado. Como se sabe, Aristóteles aplica a doutrina das causas e a intercausalidade que entre elas se estabelece à produção do conhecimento intelectual. Na concepção aristotélico-tomásica, o ato intelectivo - causa eficiente do conhecer - é imediatamente informado pela forma inteligível em ato do objeto conhecido - causa formal do conhecer. Isso acontece pela mediação da species - forma abstrata representativa do objeto. Também ela está integrada no âmbito da causa formal. A representação é medium in quo, meio no qual o ato do sujeito cognoscente se identifica intencionalmente com o ato do objeto. O objeto, conhecido pela sua forma real e não apenas representada, é a causa final do conhecimento.

Na concepção scotístico-nominalista a representação como id quod, ou o que é imediatamente conhecido, torna-se termo do ato do conhecimento. Torna-se momento inaugural dos tempos modernos do pensamento filosófico ocidental. Sua posteridade, segundo Lima Vaz, passa por Suarez, Descartes e chega a Frege e Husserl. A memória do Ser e respectiva afirmação de Deus por Lima Vaz, perante essa modernidade pós-renascimental em que vai se maturando a modernidade pós-cristã, aponta para a identidade intencional ${ }^{26}$ do ato do sujeito e do ato do objeto como fundamento noético da doutrina do significado ou sentido na acepção metafísica da existência como perfeição das perfeições.

A teoria scotista da representação ${ }^{27}$, como a entende Lima Vaz, confere novo estatuto gnosiológico à representação do objeto ou ao ser intencional

\footnotetext{
${ }^{25}$ Ver S. Th. I⿳亠口了 qq. 1-13 onde Santo Tomás assimila e transcreve a noética aristotélica em contexto cristão. A esse respeito ver Aquino, M.F. de A remodelação da Ética clássica greco-romana por Tomás de Aquino, in Filosofia Unisinos, v. 2, nº 32001 235-290, aqui 261 ss.

${ }^{26}$ Em EF III, FC 160 Lima Vaz lembra o axioma de Aristóteles: intellectus in actu est intellectum in actu. Ver Aristóteles, De Anima, III, 2, 425b 26; 7, 431르 1-2; 8, 431b 21.

${ }^{27}$ Ver EF III, FC 160-161.
} 
objetivo na imanência do sujeito cognoscente. É uma teoria do conhecimento que se orienta para a imanência do próprio sujeito, ali onde se desenrola a laboriosa produção do objeto. Opera assim inversão do sentido do vetor metafísico do conhecimento. A representação deixa de ser apenas sinal formal cuja mediação estabelece uma relação de identidade intencional do ato cognoscitivo com o objeto extramental, como na concepção tomásica da species expressa. A subordinação do objeto no seu ser real à primazia da representação, na medida em que o ser representado é, em si, primeiramente conhecido, veio a pôr ao pensamento filosófico moderno o problema da relação, na ordem do conhecimento, entre o sujeito cognoscente e o objeto no seu ser real. Duns Scotus escreveu, assim o pensa Lima Vaz, o primeiro capítulo da chamada metafísica da subjetividade.

Na concepção scotista de conhecimento, como já se viu anteriormente, a primazia da representação como sendo o objeto imediato da intenção cognoscitiva suprime, pelo menos virtualmente, a distinção aristotélica entre as três grandes formas do conhecimento: o teórico que tem como objeto a ousia (ser) das coisas investigadas e contempladas na sua verdade; o prático que tem como objeto a héxis e a areté (agir virtuoso) segundo o ethos (costume) descritas e compreendidas na sua bondade; o poiético que dirige a poíesis (fazer) de objetos segundo a sua utilidade. Uma forma de construtivismo que submete o objeto aos procedimentos operacionais definidos e estabelecidos pelo sujeito caracteriza este novo estilo de trabalho teórico, que veio a ter seu lugar de nascimento no espaço da representação. Com outras palavras, trata-se de outra fundamentação noética da doutrina do significado.

Dois pontos de chegada se destacam na sequência desse processo: o advento da modernidade renascimental, mais tarde por Lima Vaz nomeada modernidade moderna ${ }^{28}$ e, posteriormente, modernidade pós-crist $\tilde{a}^{29}$, e o desenvolvimento da metafísica moderna da subjetividade, presidida pelo modelo onto-teológico moderno. $\mathrm{Na}$ análise vaziana, a metafísica moderna ${ }^{30}$, ao encerrar a totalidade do ser na univocidade de um sistema do ser enquanto ser, oferece todas as condições teóricas para a revolução copernicana de Kant e para a substituição da instância teonômica $($ theós $=$ deus, nómos = lei) do Esse como fonte de inteligibilidade da existência, segundo o modelo criacionista, pela instância antroponômica (ánthropos = homem, nómos = lei) do sujeito transcendental.

\footnotetext{
${ }^{28}$ Ver Lima Vaz, H.C., Religião e Sociedade nos últimos vinte anos (1965-1985). Síntese 42 (1988) 27-47.

${ }^{29}$ EF III, FC 235.

${ }^{30}$ A esse propósito, ver AQUINO, Marcelo F. de. A hermenêutica heideggeriana do destino da metafísica, in CULLETON, Alfredo, STRECK, Lênio, REIS, Róbson Ramos dos (organizadores), Festschrift. Um tributo a Ernildo Stein, Editora Unisinos, São Leopoldo, 2015, 49-56.
} 
A ciência moderna apesar de ter se distanciado criticamente da concepção aristotélica de ciência, segundo Lima Vaz, continuou a se mover dentro do mesmo espaço logocêntrico. Reencontrava assim, necessariamente, o espírito e a inspiração do matematismo platônico, ainda que não a sua letra ${ }^{31}$. A posição central ocupada pela téchne como dimensão estruturante do lógos da ciência é decisivo elemento epistemológico-cultural que define a originalidade da nova ciência ${ }^{32}$. O inteligível não é mais o mundo das essências inteligíveis em-si, a cuja ordem universal e eterna o ser humano deva submeter-se e que se propõe como objeto à contemplação do Sábio. O inteligível passa a ser construído pela própria ciência. Sua verdade é uma verdade verificável segundo procedimentos experimentais hipotético-dedutíveis que constituem a estrutura empírico-formal da ciência. As estruturas da téchne no processo histórico do século XX decorrente da ciência moderna substituem progressivamente a ordem natural do kósmos, mostrando-se como destino que oprime, ou racionalidade que limita.

É oportuno referir que a escritura filosófica vaziana, a cavaleiro das décadas de 1980 e 1990, já constatava a extensão da ciência contemporânea da informática ${ }^{33}$ às ciências da natureza, sobretudo às ciências da vida. A informática desempenhando, com relação aos fenômenos da vida, o papel da matemática com relação aos fenômenos físicos. Cabe a constatação que, no século XXI, a informática está avançando rapidamente na ultrapassagem dos esquemas mentais tradicionais inerentes às técnicas e ciências diretamente ligadas ao mundo físico. A partir de seus objetos de estudo e de seus métodos de ação ela constrói esquema mental que a diferencia profundamente de todas as atividades técnicas e científicas precedentes. A informática calcula em base à informação com a ajuda de algoritmos, programas e computadores de toda espécie. A informação é codificada nos dados numéricos, o algoritmo é o mecanismo conceptual do cálculo sistemático, o programa constitui a escritura precisa do algoritmo na linguagem apropriada, e a máquina é o objeto material capaz de fazer os cálculos necessários para transformar os programas em ação ${ }^{34}$.

A primazia da representação sobre o ser é um dos traços característicos da reordenação radical das linhas de inteligibilidade com que se pensa, se interpreta e se transforma a realidade promovida pelo construtivismo moderno. A profundidade da diferença entre o $\log o s$ construtivista da ciência moderna e contemporânea e o logos contemplativo da ciência antiga e medieval se mostra, precisamente, no plano da eficácia da transformação

\footnotetext{
${ }^{31}$ EF II, EC 196.

${ }^{32}$ Ver EF II, EC 194-224.

${ }^{33}$ Lima Vaz emprega a denominação "ciências da informação". Ver AF II, nota 133, p. 48.

${ }^{34}$ A este propósito, ver Gérard Berry, L'Hyperpuissance de l'informatique. Algorytmes, données, machines, réseaux, Paris: Odile Jacob, 2017; Serge Abiteboul et Gilles Dowek, Les temps des algoritmes, Paris: Éditions Le Pommier, 2017.
} 
do mundo. O projeto da modernidade que se refaz de alguma maneira à teoria scotista do esse obiectivum, analisado a partir da teoria do conhecimento nele dominante, pode ser considerado como início do intento da humanidade ocidental de refazer a morada simbólica da sua existência no mundo e no tempo, situando-a dentro das coordenadas e das perspectivas da representação. As normas, os valores e os fins passam a ser estatuídos de acordo com os princípios axiológicos estabelecidos pelo próprio sujeito e que atendem sobretudo à satisfação das suas necessidades naturais ou artificialmente suscitadas.

À uma extremidade do arco teórico distendido pela modernidade iniciada no século XIV por Duns Scotus com sua teoria do esse objectivum corresponde outra extremidade resultada de dois eventos teóricos novos que desenham novo ciclo de modernidade. O primeiro foi o estabelecimento por Descartes nas Regulae ad directionem ingenii ${ }^{35}$ das premissas de novo modo ou novo agora na captação do tempo pela filosofia e cujas consequências repropõem em termos decididamente novos a relação do ser humano com o tempo no ato de filosofar. Trata-se da inauguração do ciclo de nova modernidade que tem como princípio a imanentização no próprio sujeito do fundamento que confere ao ato de filosofar seu privilégio no tempo. A estrutura do Eu penso como princípio do discurso filosófico avoca para si o privilégio de um começo absoluto ou da suprassunção do tempo ${ }^{36}$. Trata-se de modelo filosófico que aboliu a estrutura onto-teológica substituindo-a por outra estrutura designada onto-antropológica.

O segundo evento foi o abandono do antigo conceito de kósmos ou mundus por Kant precisamente em razão do seu caráter metafísico ao interditar a Metafísica como ciência na Crítica da Razão Pura ${ }^{37}$. Esse evento resultou da ruptura epistemológica que teve lugar no século XVII com a substituição da antiga physis, pensada a partir das qualidades sensíveis, pela natureza conceptualizada matematicamente na ciência moderna. Na concepção clássica, natureza e mundo estavam implicados um no outro. Kant separou esses dois conceitos. O mundo passou a ser o lugar das antinomias da razão pura, que tornam impossível a atribuição a ele do predicado da "coisa-em-si". Deixando de ser em-si, tornou-se uma ideia reguladora da razão pura ${ }^{38}$. Passou a integrar o domínio a priori da razão no seu uso transcategorial. A natureza passou a ser o domínio dos fenômenos, seja no seu aspecto formal como legalidade dos fenômenos no espaço e no tempo ou na sua conexão segundo leis universais, seja no seu aspecto material como totalidade dos mesmos fenômenos.

\footnotetext{
${ }^{35}$ Apesar de terem sido escritas em 1629, elas só foram publicadas após a morte de Descartes.

${ }^{36}$ EF III, FC 236-237.

${ }^{37}$ EF III, FC 200.

${ }^{38}$ Ver Kritik der reinen Vernunft B, 532 ss.
} 
A inversão do vetor metafísico do conhecimento, segundo Lima Vaz, deu o impulso inicial para a progressiva absorção da afirmação de Deus no movimento geral de constituição da razão moderna. A modernidade pós-metafísica, vertente da Metafísica da subjetividade, cumprirá sua tarefa própria de pensar Deus. A questão de Deus no pensamento vaziano dos anos sessenta e setenta do século passado acompanha seu esforço de compreender o âmbito do grande fenômeno moderno da experiência e da proclamação da morte de Deus na idade pós-sacral. Segundo a leitura vaziana da Metafísica pós-suareziana, Descartes e Espinoza inauguraram a reflexão sobre o Infinito com a afirmação da anterioridade ontológica do Infinito real sobre o finito como determinação limitada, ou sobre o Infinito como pura negação dos limites ${ }^{39}$. A desconstrução antropológica da ideia de Deus, de Espinoza a Feuerbach, tornou-se lugar obrigatório de passagem para a Filosofia pós-cartesiana. A interpretação ateísta bem como a panteísta, tornam-se paradigmas clássicos desta desconstrução.

A hermenêutica vaziana do programa sistemático-especulativo do Hegel da maturidade, levada a cabo entre o sujeito transcendental propugnado pelo racionalismo clássico e identificado com a razão, e o sujeito das carências sensíveis do empirismo e identificado no livre arbítrio ${ }^{40}$, busca compreender a expressão totalmente logicizada, em sentido hegeliano, da autonomia do Eu reivindicada pelo Eu transcendental do racionalismo clássico e pelo Eu empírico da tradição empirista. O Conceito seria essa expressão. O modo de ser próprio do Conceito é justamente a lei ontológica fundamental da liberdade: o resultado (ser posto) é, ao mesmo tempo, fundamento ou o ser em-si e para-si, e mostra-se, pois, como ser-posto de si mesmo (causa sui), tendo sua representação adequada na imagem geométrica do círculo.

Na evolução do construtivismo antroponômico do sujeito transcendental, Lima Vaz constata que os tempos modernos assistem à manifestação de dois aspectos ao mesmo tempo opostos e complementares ${ }^{41}$. De um lado a iniciativa instituidora do mundo humano atribuída ao sujeito transcendental tende a transferir-se para os grandes sistemas do saber, da práxis e da técnica que se estruturam segundo o modelo da subjetividade, como subjetividades universais, no seio das quais o indivíduo pensa age e produz. Esses sistemas, que são os sistemas sociopolíticos, as grandes teorias ou hipóteses científicas - como, por exemplo, a teoria da evolução, a hipótese do big bang etc. - e o sistema sempre mais abrangente da tecnociência,

\footnotetext{
${ }^{39}$ Numa perspectiva teológica sobre o Infinito ver David Tracy, D'une Métaphysique de l'Infini à une Théologie Trinitaire infinie, in: Philippe Capelle-Dumont e outros Métaphysique et christianisme. Vingtième anniversaire de la Chaire Étienne Gilson, Paris: PUF, 2015, ps. 69-96, aqui 89-96.

${ }^{40}$ A ideia moderna do livre arbítrio foi inaugurada por de Luis de Molina com sua definição positis omnibus requisitis ad agendum posse agere vel non agere. Cfr. Liberi arbitrii cum gratiae donis Concordiae, Madrid 1588.

${ }^{41}$ Ver EF VII, RM 144-145.
} 
constituem os círculos envolventes do que Lima Vaz chama em linguagem teilhardiana de noosfera moderna.

Ele aproxima analogicamente o Estado, a Tecnociência como organismo autorregulado de produção de conhecimento, o Mercado, enquanto camadas da noosfera moderna, da realização histórica do Conceito hegeliano. Tal analogia se estende até a Ideia absoluta - que tem em si mesma sua razão de ser ou sua inteligibilidade - ao exteriorizar-se na criação de uma nova natureza, na qual o indivíduo é integrado e arrastado assim no destino histórico da subjetividade universal e dos seus sistemas. De outro lado, a natureza que acolhe o indivíduo empírico na subjetividade universal - ou no Lógico historicamente realizado - mostra-se efetivamente multiplicada entre as várias formas de racionalidade mediante as quais opera a razão universal.

As consequências desse processo de autoconstituição da razão moderna, sejam elas ideológicas, como os ateísmos que floresceram à sombra da grande árvore da filosofia moderna, como o de Feuerbach, o de Marx, o de Nietzsche ou o de Freud, e os da multidão de epígonos reunida em torno desses grandes nomes, sejam elas epistemológicas, como a transcrição das linguagens religiosas, das crenças ou dos ritos nos códigos das racionalidades científicas que partilham entre si o campo das ciências do homem são o resultado desse processo.

\section{Nas origens da leitura de Hegel por Lima Vaz}

A experiência da relação de transcendência da Ideia absoluta na tradição grega do logos epistêmico e a experiência da relação de transcendência do Existente absoluto na tradição bíblica da palavra da revelação, segundo Lima Vaz constituem a intuição geratriz do sistema hegeliano, do qual nasce seu desafio especulativo maior. Hegel viu que o ser humano só se reconhece na misteriosa profundidade do seu ser quando se encontra face a face com a transcendência do $\log o s$ da demonstração ou da palavra da revelação. A imanentização no discurso do saber do Absoluto - a Filosofia - que é Ideia (tema da Ciência da Lógica) e do Absoluto que é Palavra mundana e histórica (tema da Filosofia da Natureza e da Filosofia do Espírito) medeia para o homem a conquista da profundeza infinita da subjetividade. $\mathrm{O}$ discurso hegeliano do saber do Absoluto tenta reduzir a estrutura meta-analógica ${ }^{42}$ do discurso filosófico cristão à univocidade

\footnotetext{
${ }^{42}$ Sobre o conceito de meta-analogia ver EF III, FC, 217. Lima Vaz reconhece no discurso cristão a presença de uma meta-analogia, que se estabelece entre a analogia entis ou analogia do ser, na sua conceptualização lógico-abstrata, obra da razão filosófica no seu exercício metafísico, e a analogia fidei na sua conceptualização lógico-concreta, obra da razão teológica no seu exercício sapiencial sobre a palavra da revelação. Ver Przywara, E., Analogia Entis; Siewerth, G., Die Analogie des Seienden; Balthasar, H.U. v., Theologie der Geschichte, ein Grundriss.
} 
de uma Lógica do Absoluto que na sua exposição no saber do homem, tornado Saber Absoluto no filósofo, atesta nele a imanência da subjetividade infinita: Espírito Absoluto.

No transcorrer de sua segunda jornada filosófica ${ }^{43}$ nos inícios dos anos sessenta, Lima Vaz abraçou o complexo desafio posto pela modernidade pós-renascimental de reordenação da inteligibilidade da realidade. Seguiu para tanto a trilha da correspondência entre consciência histórica cristã e consciência histórica moderna ${ }^{44}$, aludida em precedente artigo. Esse debate teórico entre metafísica da ordem (táxis) como matriz fundamental de inteligibilidade e o Eu na sua estrutura transcendental transparecia nos textos vazianos da época. A noção clássica de táxis levada em consideração por Lima Vaz transitava pelos modelos propostos por Platão, Aristóteles, Plotino, Pseudo-Dinísio Areopagita, Santo Agostinho, Santo Tomás ${ }^{45}$. Cabe observar, por oportuno, que, nessa sua segunda jornada filosófica, Lima Vaz se ocupou intensamente com Teilhard de Chardin. Em Raízes da Modernidade é possível recuperar evidências esparsas aqui e acolá da consistente e audaciosa aproximação vaziana de Tomás de Aquino, Hegel e Teilhard de Chardin ${ }^{46}$.

À cavaleiro da sua segunda e terceira jornada filosófica, Lima Vaz se depara com o interdito kantiano à possibilidade da Metafísica como ciência: ao em-si do Absoluto no âmbito do cognoscível e sua redução a cimo ideal do pensável na arquitetônica da razão pura. Ele se debruça sobre a solução hegeliana à aporia do pensamento por nossa razão situada e finita, ao fazer do para nós do Absoluto a raiz da inquietação da mais radical Verzweiflung (dúvida) da consciência, o que a impele a percorrer dialeticamente as formas da sua finitude, até que essa finitude seja suprassumida no Saber Absoluto. O pensamento do Absoluto (gen. subj.) ou o Absoluto pensante emerge aqui como suprassunção do pensamento humano do Absoluto ou do Absoluto pensado. Como Ideia, como Natureza e como Espírito, ele é o sujeito verdadeiro do lógico, do natural e do histórico ${ }^{47}$.

Lima Vaz modela conceitualmente a afirmação de Deus ao longo destas duas jornadas sob a experiência da presença antropológico-cultural do movimento de transcendência, em que o termo transcendência recebe uma

\footnotetext{
${ }^{43}$ Para a compreensão das jornadas filosóficas propostas pelo próprio Lima Vaz a propósito do seu itinerário filosófico, ver Morte e Vida da Filosofia, Síntese Nova Fase, 1991, p. 677-691. 44 No percurso dessa trilha, ele buscava nova forma de diafania de Deus no mundo visível para que a palavra histórica de Deus pudesse chegar até nós através de uma estrutura objetiva de sinais. Tratava-se então, segundo ele, de fazer com que essa diafania passasse necessariamente, pela iniciativa cosmopoiética do homem (construção do mundo). Nesse sentido, nela se dará realce à diafania do Espírito que age, como intermediário da diafania do Logos que ordena.

${ }^{45}$ EF VII, RM 206-207.

${ }^{46}$ EF VII, RM 127.

${ }^{47}$ Cfr. AF II, 120.
} 
significação antropológica bem definida. Designa o movimento intencional com o qual o ser humano transgride, sob formas diversas, os limites da sua situação no mundo e na história, e se lança na direção de uma suposta realidade transmundana e transhistórica, na qual se descobre um como cimo ou coroa de todo o sistema simbólico, capaz de unificar as razões com as quais os indivíduos e as sociedades procuram um sentido ao seu estar no espaço e no tempo.

Ele rememora a experiência da relação de transcendência na Filosofia grega, bem como a experiência da relação de transcendência na Aliança da Revelação bíblico-cristã. No caso da Filosofia, ele acompanha o movimento de anábasis da alma ao Absoluto mediante a qual essa chega à Ideia suprema, i. é, o Ser-Uno na concepção onto-henológica, ou o Princípio na concepção teológica. No caso da Aliança, acompanha a katábasis do Absoluto mediante a qual esse se doa como Existência na Criação e na Encarnação ${ }^{48}$. A experiência da ideia na Grécia e a experiência da Palavra de Deus em Israel põe em evidência o problema do Princípio ou do fundamento último do Ser. Essas duas experiências expressam o Princípio, respectivamente, ou como Absoluto de essência, ideia suprema, ou como Absoluto de existência, causa eficiente.

Que hermenêutica Lima Vaz usará para interpretar esse movimento de transcendência sem se enredar no reducionismo da suspeita ou do interdito lançados sobre o problema do Absoluto na Filosofia pós-hegeliana ${ }^{49}$ ? Do ponto de vista da estrutura relacional do ser humano que ele desenhou na sua Antropologia Filosófica, a relação de transcendência exprime como que o excesso ontológico pelo qual se sobrepõe ao mundo e à história e avança além do ser-no-mundo e do ser-com-o-outro, buscando um fundamento último para o $E$ u sou primordial que o constitui. Esse excesso ou superabundância ontológica Lima Vaz o conceptualiza filosoficamente pela noção de espírito em sua irredutibilidade ao somático e ao psíquico ${ }^{50}$, categorizando-a como relação de transcendência. Ele a pensa em sua conceptualidade antropológica como constitutivo ontológico do ser humano, mostrando-se necessariamente como suprassunção dialética da oposição entre exterioridade e interioridade. Nela o sujeito situado na exterioridade do mundo e da história é, ao mesmo tempo, aberto interiormente à universalidade do Ser. O sujeito da relação de transcendência é uma abertura intencional à infinitude do Ser. Nesse horizonte de abertura, próprio da imanência do sujeito, o pensamento pensa o Absoluto transcendente, seja como Absoluto formal (Ser, Verdade, Bem) seja como Absoluto existencial, (Deus). A relação de transcendência por parte do ser humano ao Absoluto

\footnotetext{
${ }^{48}$ Cfr. AF II, 117 e EF III, FC 211-214.

${ }^{49}$ Cfr. Transcendência: História e Teoria, in EF III, FC 193-221, aqui 198.

${ }^{50}$ Cfr. Transcendência: História e Teoria, in EF III, FC, 193-221, aqui 200.
} 
é uma relação não recíproca por parte do mesmo Absoluto que não pode ser pensado, por definição, segundo uma relação real ad extra.

Em texto ${ }^{51}$ de meados dos anos 1970, Lima Vaz tangenciou Hegel a partir de Santo Tomás. Sem pretender ler Santo Tomás com as categorias de Hegel, ele mostrou que o pensamento de Tomás de Aquino, bem como o de Hegel, são um pensamento da totalidade ou da identidade na diferença. Qualquer dualidade, ou melhor, qualquer dualismo ${ }^{52}$ como pressuposição fundamental lhes era intolerável. Ambos pensaram a partir de uma dialética da unidade ou da identidade radical, segundo a qual a diferença ou dualidade é posta como refletida na unidade original e assumida dialeticamente na unidade final ${ }^{53}$. A hermenêutica vaziana dos textos de Tomás de Aquino repensa a descentração do espaço espiritual do ser humano em sua harmonia com o kósmos inerente ao humanismo clássico ${ }^{54}$. Lima Vaz tangenciou Hegel a partir da emergência da liberdade como liberdade humana por parte da revelação cristã que transgrediu os limites dentro dos quais o homem antigo encerrava suas possibilidades de ser livre ${ }^{55}$.

Lima Vaz antecipava a problemática oscilação do lugar da liberdade, por um lado com sua inserção na necessidade objetiva do universo científico-tecnológico da modernidade contemporânea, que impõe racionalização crescente às esferas do econômico, do social e do político, e por outro lado a gratuidade originária do ato livre em cujo nome a subjetividade contesta e se insurge contra o domínio implacável das estruturas ${ }^{56}$. O focal meaning desse texto, em que ele estuda a remodelação do cognitivismo aristotélico e neoplatônico por Santo Tomás, deixava antever a remodelação do cognitivismo de matriz dialético-especulativa de Hegel. O que antecipa, de certa maneira, a evolução do pensamento vaziano em sua terceira jornada filosófica.

Segundo Lima Vaz, Hegel pôs a questão da possibilidade de um equilíbrio ou mesmo uma conciliação entre o ideal antigo da autárqueia (autossuficiência) e a liberdade cristã ${ }^{57}$. Na esteira desse grande tema hegeliano, ele reconhece que a tensão e o equilíbrio entre, por um lado, o universo fechado das estruturas racionais que modelam cada vez mais profundamente a

\footnotetext{
${ }^{51}$ Ver "Tomás de Aquino e o nosso tempo: o problema do fim do homem" in EF, PF 34-70, aqui 48. Esse texto foi anteriormente publicado sob o título "Teocentrismo e beatitude: sobre a atualidade do pensamento de Santo Tomás de Aquino" in Revista Portuguesa de Filosofia, 30 (1974), 39-78. Ver também a segunda parte do presente artigo in Síntese, Belo Horizonte, v. 44, n.138, p. 30-73, jan./abr., 2017, aqui 54-56.

${ }^{52}$ É oportuno registrar que o uso semântico dos conceitos "dualidade" e "dualismo" por Lima Vaz em alguns casos é escorregadio, com certa conversão de um pelo outro.

${ }^{53} \mathrm{EF}, \mathrm{PF} 56$.

${ }^{54}$ EF, PF 34-35. Nesse sentido, Lima Vaz opera com o conceito de cosmocentrismo.

${ }^{55}$ Nesse caso opera com o conceito de teocentrismo.

${ }^{56} \mathrm{Cfr}$. EF, PF 38.

${ }^{57} \mathrm{EF}, \mathrm{PF} 36$.
} 
existência do indivíduo e, por outro lado, a liberdade que irrompe como exigência de sentido para essa mesma existência singular e historicamente situada é um dos maiores problemas filosóficos contemporâneo ${ }^{58}$.

Cabe destacar que Lima Vaz não pretendia alimentar polêmicas teológicas acumuladas ao longo dos séculos a propósito do livre-arbítrio e do fim último do homem ${ }^{59}$ nos textos de Santo Tomás. Ele pretendia, num exercício de anámnesis (rememoração ou Erinnerung), abrir-se ao campo da presença ou da experiência em que Santo Tomás se colocou, subjacente ao seu ensinamento sobre liberdade e beatitude. Tomás de Aquino concebe a relação entre liberdade e beatitude levando em consideração dois polos. Um é formado pela complementariedade entre a noção aristotélica de natureza como princípio interno de movimento dos seres que lhes confere sua consistência própria num universo ordenado segundo os círculos ascendentes das naturezas ou essências, e a visão neoplatônica do movimento $\mathrm{d} \backslash$ e processão e retorno dos seres ao seu princípio. $\mathrm{O}$ outro é formado pela descentração do ser humano operada pela revelação bíblica judaica e cristã que o arranca do círculo lógico da sua definição, em sentido aristotélico, e da necessidade como que dialética da conversão, em sentido neoplatônico.

A liberdade cristã surge, nesse texto vaziano, como contraponto à autárqueia alcançada pela theoría (contemplação) do Sábio e que flui inteiramente da adesão intelectual à ordem ${ }^{60}$ dos inteligíveis coroada pelo Inteligível supremo. A contemplação do universo das essências pelo Sábio na calma eternidade da sua ordem objetiva para superar a precariedade da sua existência individual e consequente conquista da felicidade integram conceitualmente o cognitivismo clássico grego. A liberdade cristã, por sua vez, irá definir-se como situação do ser humano pecador nas peripécias de uma história ou de um drama em que sua livre decisão se abre ou deve abrir-se ao acolhimento do dom divino. Não mais um mundo de ideias que eleva o contemplante à perfeição da sua eternidade, mas um amor pessoal que vem ao encontro do ser humano pelos caminhos da própria história. Com outras palavras, Deus advém absolutamente à humanidade pelos caminhos relativos da história.

A beatitude como fim último do homem foi o terreno onde Lima Vaz buscou novo sentido à dialética entre natureza e fim, conferido pelo cognitivismo cristão e não pelo cognitivismo aristotélico e neoplatônico. O cognitivismo grego $^{61}$ é, estruturalmente, uma forma de pensamento dualista que caminha

\footnotetext{
${ }^{58} \mathrm{EF}, \mathrm{PF} 40$.

${ }^{59} \mathrm{EF}, \mathrm{PF} 36$.

${ }^{60}$ Sobre a categoria de ordem ver Marcelo Fernandes de Aquino, Raízes e formação da teologia cristã, in André de Melo Araújo et alii, Entre Filosofia, História e Relações Internacionais. Escritos em homenagem a Estevão de Rezende Martins, São Paulo: Editora Libera Ars, p. 84-86. ${ }^{61} \mathrm{EF}, \mathrm{PF} 65$.
} 
para a unidade do Princípio a partir da diferença dos seres, da sua multiplicidade, cuja franja extrema é a multiplicidade original e irredutível da matéria eterna. A noção aristotélica de natureza como princípio interno de movimento dos seres que confere sua consistência própria num universo ordenado segundo os círculos ascendentes das "naturezas" ou essências, e a visão neoplatônica do movimento de processão e retorno dos seres com relação ao seu princípio ${ }^{62}$ compõem conceitualmente o cognitivismo clássico grego do universo das essências na calma eternidade da sua ordem objetiva. O dinamismo imanente da natureza e a presença necessária do fim são, portanto, as coordenadas fundamentais da representação cognitivista grega centrada no kósmos ${ }^{63}$. Isso significa: a beatitude é função da perfeição própria da natureza (perfeição do universo) ou do retorno do universo ao seu princípio (inteligibilidade do todo).

O espaço do cognitivismo aristotélico e neoplatônico é cósmico. O evento em sua unicidade, pensado segundo a concepção aristotélica e a concepção neoplatônica, é pura contingência em face da ordem eterna das essências. A beatitude é pensada, respectivamente, ou como operação perfeita da natureza racional ou como retorno ao Princípio.

O espaço do cognitivismo cristão, por sua vez, é histórico. Nele o tempo torna-se dimensão privilegiada em que se desenrola uma cadeia de eventos significativos que se articulam numa história da salvação. Da parte da criatura, implica relação de indigência, mas não de exigência. Da parte de Deus, fim último e objeto da beatitude, não implica qualquer relação real que viria a incluí-lo na totalidade do kósmos - o divino por excelência, do qual seria o Princípio ordenador e o fim contemplado, mas não, estritamente, o Criador. A beatitude do ser humano é um dom que emana da infinita gratuidade da fonte primeira do ser. Para Santo Tomás ${ }^{64}$ a visão da divina essência depois desta vida, cuja possibilidade e realidade nos são dadas a conhecer pela revelação, é a única beatitude perfeita para o ser humano verdadeiramente digna deste nome,.

O nó górdio dessa discussão de Lima Vaz com o cognitivismo aristotélico da natureza e o cognitivismo neoplatônico da processão e do retorno, a epocalidade que ele reconhece no pensamento de Tomás de Aquino, está na superação radical do exemplarismo das essências eternas contempladas, em que se fundamenta a representação grega do kósmos como uma unidade de ordem ou como um todo autossuficiente ${ }^{65}$. O centro de inteligibilidade a partir do qual a crítica à representação cognitivista grega, que se constitui igualmente em manifestação da verdade em Santo Tomás, assim o

${ }^{62}$ EF, PF 38-39. Para uma apresentação do conceito de natureza do ponto de vista antropológico-filosófico ver AF II 14-36.

${ }_{63} \mathrm{EF}, \mathrm{PF}$ 54-55.

${ }^{64} \mathrm{EF}, \mathrm{PF} 48-49$.

${ }^{65} \mathrm{EF}, \mathrm{PF} 59$. 
pensa Lima Vaz, está na exemplaridade absoluta do ato de existir ${ }^{66}$. Cabe recordar que a tradição platônico-aristotélica transmitiu a Tomás de Aquino uma concepção dinâmica do juízo como afirmação do ser, em que a alma assume uma atitude ativa com relação ao dado ${ }^{67}$, inserindo-o no plano da existência. A inteligência exprime formalmente no juízo sua conformidade com o objeto, constituindo-o em seu ser de objeto e libertando-o das condições subjetivas da assimilação ${ }^{68}$. O termo próprio do juízo já não é a natureza ou essência, mas a existência, esse rei $i^{69}$. A existência é ato primeiro e perfeição das perfeições: perfectio omnium perfectionum..$^{70}$

O pensamento de Tomás de Aquino está diante de duas dialéticas: a dialética da concepção grega de filosofia, e a dialética do pensamento cristão patrístico e medieval. A primeira, que é essencialmente teológico-cosmológica, se volta para o mundo como grandeza teológica na sua eternidade e perfeição na qual a identidade é perseguida a partir de uma diferença que se mostra finalmente irredutível. A segunda, que é essencialmente teológico-histórica encontra na obra de Tomás de Aquino com sua metafísica do ato de existir, a abertura para o pensamento da história como diferença da identidade absoluta original e que se opõe ao pensamento do kósmos como identidade relativa conquistada sobre a diferença absoluta original da eternidade da matéria. A identidade original do Absoluto, plenitude do existir, que se autodiferencia ad intra (processões trinitárias) e que mantém, na diferença ad extra (criação), a identidade do movimento real ou histórico da criatura racional no retorno ao seu Princípio ou no caminho para sua beatitude final, torna-se o fundamento do pensamento tomásico.

\section{Lima Vaz leitor de Hegel: Filosofia como hermenêutica cultural}

Lima Vaz constata que a instauração suareziano-cartesiana da Metafísica da subjetividade chegou ao seu completamento com Hegel. A transposição da Metafísica do ser na lógica da Metafísica da subjetividade como legítima herdeira da antiga Metafísica do absoluto transcendente, configura a leitura vaziana do programa sistemático-especulativo tardio de Hegel. Ora, essa Metafísica só se tornou possível com a exposição de novo conceito de ser como sujeito absoluto cujo saber de si mesmo é, ao mesmo tempo e exatamente, a manifestação do ser na sua inteligibilidade, expressividade e coerencialidade radicais: das Denken (puro pensar $)^{71}$.

\footnotetext{
${ }^{66}$ Ver Itinerário da ontologia clássica, agora in EF VI 57-76, aqui 69-76.

${ }^{67}$ Cfr. De Veritate, q. I a 10 c: anima inquantum judicat... magis quodammodo agit.

${ }^{68}$ Cfr. Contra Gent., C. 59.

${ }^{69}$ Cfr. De Veritate, q. I a. 1 c; In Boeth. De Trin. Q. V a. 3 c.

${ }^{70}$ Cfr. De Pot., q. VII a. 2 ad 9m; I q. 3 a. 4 c.

${ }^{71}$ Ver Henrique Cláudio de Lima Vaz, Sobre a significação da Lógica hegeliana: glosas marginais, in Verdade, Conhecimento e Ação. Ensaios em homenagem a Guido Antônio de Almeida e Raul Landim Filho, orgs. Edgar da R. Marques e outros, São Paulo: Loyola, 1999, 409-416.
} 
A partir dos albores da modernidade renascimental, a noção de sistema ${ }^{72}$ adquiriu tecnicidade instrumental e rigor formal que a tornaram a mais eficaz e poderosa matriz organizacional da vida e das ideias na cultura contemporânea do Ocidente ${ }^{73}$. A necessidade da presença insubstituível da filosofia num mundo de cultura em que as razões se multiplicam e se organizam em sistemas e subsistemas, envolvendo toda a vida dos humanos e das comunidades humanas é um dos legados hegelianos recolhidos por Lima Vaz. Para ele, a recusa dessa necessidade da filosofia só teria como alternativa a vã contestação niilista que acompanharia, com o clamor da desrazão sistêmica, a rota de uma civilização que teria perdido sua alma.

A hermenêutica do pensamento de Tomás de Aquino proposta por Lima Vaz faz parte do marco referencial teórico do seu programa filosófico-sistemático tardio de criticar o cognitivismo sistêmico moderno e contemporâneo. Parte da manifestação da inteligibilidade fontal ou primordial do $e s s e^{74}$ como enérgeia (ato ou perfeição): intuição mais simples e mais profunda da nossa inteligência ${ }^{75}$. Procede per viam compositionis na exposição da metafísica do Esse absoluto. Com outras palavras, Lima Vaz avança num

${ }^{72}$ Em EF V, IEF II, 12 Lima Vaz afirma que "O termo sistema" é a transliteração do grego sýstema, proveniente do verbo synistánai, que significa "estar de pé" ou "estou de pé". Da acepção metafórica inicial aplicada a significar "conjunto" ou "reunião", o termo sýstema foi empregado para designar o discurso (logos) cujas partes se inter-relacionam por meio de conexões lógicas de sorte a formar um todo ordenado segundo critérios de natureza lógica. A definitiva transposição filosófica do termo sýstema deve-se aos estoicos que o aplicaram à totalidade do universo ordenado (kósmos), vindo a designar posteriormente o todo do discurso filosófico em suas três partes: Lógica, Física e Ética.

${ }^{73}$ A esse propósito, cabe lembrar que Lima Vaz, em sintonia com a leitura medieval dos capítulos 1 a 3 do livro IV (delta) da Metafísica, que determina o objeto da ciência primeira e estabelece sua unidade segundo a estrutura analógica prós en, ou referência a um significado primordial, no caso a ousía, posteriormente apropriada por Tomás de Aquino como doutrina do próprio Aristóteles, seguiu atribuindo a Aristóteles a doutrina que desencadeou sua concepção analógica do discurso sistemático. Com efeito, ao reconhecer a pluralidade dos diferentes usos da razão ou de formas distintas de racionalidade obedecendo a métodos distintos segundo a diferença dos seus objetos, Aristóteles teria sido levado a introduzir uma distinção de diversos tipos de saber correspondentes a diversos usos da razão e, portanto, a diversos formas do discurso demonstrativo. Ver Síntese, Belo Horizonte, v. 44, n. 138, p. 61-62. ${ }^{74}$ Aqui cabe citar extensamente EF VII, RM 95: "Do ponto de vista metodológico, nosso roteiro procede inicialmente seguindo a chamada via compositionis: parte da intuição e afirmação originárias do esse e desenvolve as implicações lógico-dialéticas dessa posição inicial. Ao termo do percurso, novamente nos encontramos no princípio, obedecendo a uma modalidade da via resolutionis, que é, ao mesmo tempo, instauração de uma totalidade de estrutura dialética. Como dialética, essa totalidade realiza, a nosso ver, de maneira paradigmática, a natureza de um sistema aberto, já que seu termo é o reconhecimento de um hiato metafísico infinito, intransponível pelo discurso, que, ao mesmo tempo, separa a esfera dos entes relativos da esfera do Esse absoluto, e com ela a articula pela via da causalidade.". Ver ainda a nota 1 nesta mesma página: "O método normal da metafísica, segundo Aristóteles e Tomás de Aquino, segue a via resolutionis, vindo a metafísica (filosofia primeira ou teologia) após a física. Cremos, no entanto, que o uso da via compositionis em chave dialética, como aqui propomos, está de acordo com a estrutura teórica da metafísica tomásica do esse.".

${ }_{75}$ EF VII, RM 187. Sobre a hyperbolé platônica ver Rep. VI, 509 c 2; sobre a epékeina ver Rep., 509 b 9. 
percurso de natureza lógico-dialética, no qual se desdobrou a inteligibilidade intrínseca do Esse e que se completa com o retorno ao ponto de partida, quando o Esse manifesta sua identidade absoluta na diferença da infinita autodeterminação com que se pôs reflexivamente como Bem. A exposição vaziana desenvolve, para tanto, as implicações lógico-dialéticas dessa posição inicial. Ao termo desse percurso metafísico, retorna novamente ao princípio, e assim instaura uma totalidade de estrutura dialética. Como dialética, essa totalidade realiza, de maneira paradigmática, a natureza de um sistema aberto, já que seu termo é o reconhecimento de um hiato metafísico infinito, intransponível pelo discurso, que, ao mesmo tempo, separa a esfera dos entes relativos da esfera do Esse absoluto, e com ela a articula pela via da causalidade ${ }^{76}$.

A abertura à transcendência inobjetivável do Absoluto, no hiato ontológico da diferença, que traduz a hyperbolé (excesso) do Ser, para usar uma expressão platônica, que é absolutamente Uno e, como tal, Verdadeiro e Bom, torna-se possível graças à estrutura analógica da metafísica do esse. A epékeina do Ser, ou seja, seu estar infinitamente além dos seres finitos, permite-os existir na sua autonomia.

O roteiro filosófico de Lima Vaz se cumpre expondo a passagem da primazia da inteligibilidade da essência para a primazia da inteligibilidade da existência, que assinalou a substituição do arquétipo eternista do pensamento antigo pelo arquétipo criacionista das teologias monoteístas. E mais radicalmente da teologia cristã-medieval, da qual irá originar-se o caráter instituidor de sentido e demiúrgico do sujeito transcendental moderno ${ }^{77}$, escopo da severa metacrítica cultural à Metafísica da subjetividade por ele levada a cabo.

Ora, se se leva em conta o fato de que a explicitação formal da noção de sistema teve lugar historicamente na tradição filosófica, se entende por que o problema da relação entre filosofia e cultura adquiriu surpreendente atualidade no roteiro filosófico vaziano como metacrítica cultural, tendo passado a iluminar seu programa sistemático-especulativo tardio. Com outras palavras, o novo estilo de trabalho teórico perseguido por Lima Vaz se realiza como metacrítica cultural. Nesse sentido, a onipresença

\footnotetext{
${ }^{76}$ EF VII, RM 129.

${ }^{77}$ EF VII, RM 145 “Parece, à primeira vista, arbitrária e gratuita a hipótese de um crescimento da metafísica moderna da subjetividade a partir de raízes teológicas nascidas nas controvérsias do século XIII. Na verdade, tal hipótese seria insustentável se a considerássemos como uma hipótese a ser verificada a partir de uma sequência cronológica de textos lidos na sua literalidade. Pensamos, no entanto, que pode ser aceita se tentarmos confirma-la através dessa espécie de Wirkungsgeschichte (história dos efeitos) silenciosa e quase imperceptível que o conteúdo simbólico profundo das ideias exerce sobre os espíritos". Ver ainda EF VII, RM 222 "Se o modelo onto-teológico surgiu da rejeição da metafísica do esse, é nessa, segundo nos parece, que devem manifestar-se os indícios longínquos da instauração moderna da metafísica da subjetividade".
} 
cultural do cognitivismo sistêmico foi, talvez, o mais grave problema entre quantos se levantavam diante de Lima Vaz na rota da sua terceira jornada filosófica. Cabe destacar que em texto ${ }^{78}$ de 1995 Lima Vaz já exprimia sua preocupação com a solução radical não filosófica proposta pelas ciências cognitivas para o problema do começo da razão, reduzindo sua origem aos supostos mecanismos elementares do seu funcionamento através do paralelismo e da simulação entre os modelos da inteligência artificial e a estrutura neurofisiológica e a atividade do cérebro humano. Segundo o entendimento vaziano, essa seria uma tentativa vã, pois uma distância incomensurável separa a autorregulação da inteligência artificial, que procede essencialmente por cálculo e programa, e a reflexividade da razão, patente na sua autoproblematização e na possibilidade do conhecimento do conhecimento.

Perante essa aparentemente irresistível expansão da racionalidade sistêmica como estrutura simbólica básica da nossa civilização, a hermenêutica vaziana dos textos hegelianos passou a reclamar a necessidade de reflexão filosófica sobre a cultura contemporânea. Sendo a história o lugar da aparição, da trabalhosa realização e do destino da liberdade, e estando a história regida cada vez mais pela racionalidade sistêmica, como o foi até agora pela irracionalidade da violência, ele se perguntava: poderia a liberdade, apenas saída da pré-história da violência, florescer nas áridas planícies de uma história feita sistema? Pensar a liberdade, ou seja, unir dialeticamente razão e liberdade na civilização científico-tecnológica é uma das mais importantes tarefas da filosofia na metacrítica cultural vaziana.

Em decorrência da tarefa de pensar a liberdade, Lima Vaz pôs-se o problema eminentemente filosófico da autodiferenciação da razão em geral, dando-lhe tratamento tanto sob o ponto de vista teórico como do ponto de vista histórico. Essa questão da autodiferenciação da razão foi posta, desde o início, na própria natureza da razão, ou seja, na abrangência teórica do campo da conceitualização filosófica. Sua própria formulação está implicada na emergência de uma forma de razão que se tornou paradigmática: a razão filosófica.

O aparecimento da razão filosófica é assinalado pela aporia inicial com que se envolve a própria razão nos seus primeiros passos, ao buscar no terreno do mito o problema da arquê (começo) e ao tematizar assim a questão sobre seu próprio começo Conforme a leitura vaziana do pensamento clássico grego, as primeiras construções sistemáticas da razão filosófica em Platão e Aristóteles já explicitaram a abertura transcendental da razão ao ser, ou seja, sua identidade dialética com o ser, e sua total reflexividade em si mesma como propriedades que a definem plenamente. Reflexão e

${ }^{78}$ Cfr. Ética e Razão moderna, Síntese Nova Fase, v.22, n. 68 (1995): 53-85, aqui 59-69. 
consciência formam o passo decisivo que assinala o aparecimento da razão e que a leva, ao atingir a plena autoconsciência, a defrontar-se com o paradoxo de pensar sua própria origem e de desdobrar-se na interrogação sobre si mesma. A identidade com o ser e a reflexividade permitem atribuir uma unidade analógica à razão. Segundo essa unidade suas formas se diferenciam em virtude da referência a uma forma paradigmática na qual se manifesta, na sua realização considerada a mais perfeita, a essência ou a ideia da razão.

A razão filosófica no seu exercício metafísico foi reconhecida, ao longo de muitos séculos, como sendo o foco primeiro de significação ou analogado principal nessa estrutura analógica. Foi mantida mesmo quando a fé, forma transracional de saber, passou a ser reconhecida como fecho da abóboda do conhecimento humano. Ora, a modernidade pós-cristã caracteriza-se por uma ruptura da estrutura analógica da razão. Vários modelos de racionalidade, por exemplo físico-matemática, dialética, lógico-linguística, fenomenológica, hermenêutica, reivindicam a sucessão da antiga razão metafísica. Segundo Lima Vaz não logram unificar o campo da razão após a dissolução do noûs que coroava o exercício da atividade racional com a theoría do Ser e a ascensão intelectual ao Absoluto ${ }^{79}$.

A autodiferenciação da razão põe problema metafísico, gnosiológico e histórico no qual se entrelaçam, formando o nó inicial do longo fio do destino da razão no tempo lógico da sua autodiferenciação e no tempo histórico das suas formas sucessivas. No primeiro caso, Lima Vaz investiga o princípio da autodiferenciação da razão e da multiplicação das racionalidades na sua realização histórica. No segundo caso, ele considera a gênese e o crescimento multiforme da razão naquela civilização que se tornou emblematicamente a "civilização da razão": a civilização ocidental. Três grandes questões se entrelaçam na questão sobre o próprio começo da razão: a identidade dialética da razão e do ser, a identidade reflexiva da razão consigo mesma e a unidade da razão na pluralidade das suas formas e de seus usos.

\section{A inversão vaziana da inversão hegeliana da hierarquia clássica dos saberes}

Entre 1988 e 1989 Lima Vaz pesquisou e interpretou a filosofia hegeliana em seu caráter quase arquetípico de articulação da lógica da absolutização do saber na imanência do sujeito. A saber, em seu caráter de paradigma da racionalidade sistêmica e, por isso mesmo, código de leitura mais completo e profundo do discurso metafísico subjacente à filosofia mo-

\footnotetext{
${ }^{79}$ Ver AF I, 243-289.
} 
derna $^{80}$. Entre 1991 e 1992 reconstruiu em dois longos artigos ${ }^{81}$ o quadro referencial teórico da experiência de transcendência na modernidade pós-cristã em suas dimensões filosófica, teológica e religiosa. Posteriormente, em 1993 publicou texto ${ }^{82}$ em que analisou os modelos platônico e hegeliano de filosofia. Para tanto, expôs em sua inteligibilidade o movimento do lógos filosófico de introduzir a ordem que procede do Uno na desordem fenomênica do múltiplo. Ou ainda, expôs o sentido da redução ordenada do múltiplo ao Uno ${ }^{83}$, fazendo para tanto uma hermenêutica genuinamente filosófica da cultura do nosso tempo ${ }^{84}$. Finalmente, entre 1997 e 2001 redigiu conjunto de textos reunidos em 2002 volume VII dos Escritos de Filosofia 85 em que discute o quadro referencial histórico da modernidade formado pelo universo simbólico das razões elaboradas e codificadas na produção intelectual do Ocidente nesses últimos quatro séculos, que se apresentam como racionalmente legitimadas e a partir do qual Hegel desponta.

Os modelos platônico e hegeliano de filosofia, no âmbito da terceira jornada filosófica vaziana, reivindicam exemplaridade que provoca sua atenção e consequente reflexão. Não obstante tenaz preconceito que apresenta Platão e Hegel como filósofos da necessidade da razão que tiraniza a liberdade, Lima Vaz procurava mostrar que o caráter emblemático dos modelos platônico e hegeliano na tradição ocidental das relações entre filosofia e cultura provém do gesto especulativo com que eles pensaram a Liberdade no próprio coração da necessidade racional que preside à construção do sistema das razões universais e tende a instaurar uma ordem translúcida às razões individuais, numa história enfim sensata. $\mathrm{O}$ Bem para Platão e o Espírito para Hegel significam ao mesmo tempo o Princípio absoluto de toda inteligibilidade e o supremo paradigma da liberdade como absoluta autodeterminação: o Bem como Ideia na perspectiva da ontologia antiga, o Espírito como Sujeito segundo o postulado da Metafísica moderna, mas que Hegel irá ler na esteira da nóesis noéseos aristotélica.

Lima Vaz se pergunta: como a transcendência absoluta assegurada ao Bem platônico pelo esquema vertical do noûs ou inteligência espiritual pode ser afirmada igualmente do Espírito hegeliano que obedece ao esquema

\footnotetext{
${ }^{80}$ Ver FPH 83-136.que edita o Relatório de Pesquisa "A construção hegeliana: um paradigma da racionalidade sistêmica" CNPQ - Processo 301665/87-7. Texto que atesta a envergadura da atividade investigativa de Lima Vaz.

${ }^{81}$ Ver Religião e modernidade filosófica, Síntese, n. 53, 1991, p. 147-165, agora sob o título Transcendência e religião: o desafio das modernidades, EF III, FC 223-253; Transcendência: experiência histórica e interpretação filosófico-teológica, Síntese, n. 59 (1992): 443-460, agora sob o título Transcendência: História e Teoria EF III, FC 193-221.

${ }^{82}$ Filosofia e Cultura na tradição ocidental, Síntese, n. 63, 1993, p. 533-578, posteriormente publicado sob o título Filosofia e Cultura: perspectiva histórica, in EEF III, FC 3-80. Nesse texto, Lima Vaz expõe os modelos platônico e hegeliano de filosofia em seu exercício de hermenêutica filosófica da cultura do nosso tempo.

${ }^{83}$ EF III, FC 55.

${ }^{84}$ EF III, FC 16.

${ }^{85}$ EF VII, RM.
} 
horizontal da sua manifestação progressiva na Natureza e na História? O núcleo conceptual mais profundo da relação entre filosofia e cultura, que se encontra formulado com vigor incomparável no próprio coração dos modelos platônico e hegeliano, é que neles a liberdade não é exterior à razão, mas é intrínseca ao movimento da sua autoconstituição mesma. Desta sorte, ela não é antagônica ao sistema das razões que tem seu Princípio no Bem ou no Espírito, confrontando-o na contestação ou sendo por ele oprimida como coerção.

Esse movimento se cumpre para Platão seguindo o esquema vertical da anábasis e da katábasis, e o Uno preside a ordem do múltiplo sob a forma do Bem. Organiza como universo essa ordenação do múltiplo sob a forma do Bem. Para Hegel o movimento procede segundo a linha horizontal de um desenvolvimento dialético no qual o Princípio, que é o Uno, organiza o múltiplo segundo os estágios da sua manifestação enquanto Espírito. Organiza como história a ordenação dialética do múltiplo ao $\mathrm{Uno}^{86}$. A ordem que procede do Uno, tanto para Platão como para Hegel, é sempre um retorno à unidade original. Para Lima Vaz, o logos filosófico, citando a famosa definição do verdadeiro dada por Hegel no Prefácio da Fenomenologia do Espírito como "o círculo que pressupõe seu fim como sua meta ou o tem como seu princípio" 87 , é o eikon (imagem) no tempo do círculo eterno da verdade.

Como pensar o fluxo de inteligibilidade que procede do Uno como Absoluto sem perder-se na indeterminação do "mau infinito"? Esta é importante questão que Lima Vaz se põe. A inteligibilidade que procede do Uno só pode ser adequadamente pensada como retornando ao Princípio que se conceitua como mediatizada seja pela ordem do universo em Platão, seja pela ordem da história em Hegel.

Segundo Lima Vaz, este é o roteiro seguido por Hegel na Ciência da Lógica que se pretende ser herdeira da Metafísica clássica. Nela o desdobramento dialético do Sein é, igualmente, Begriff - emergência do sujeito na sua forma pura - e, finalmente, Absolute Idee, totalidade inteligível em sua coerência. A identidade dialética de subjetividade e objetividade funda, para Hegel, a necessidade inteligível - que é também perfeita Liberdade - da exteriorização da Ideia Absoluta em Natureza e Espírito, na qual ela suporta e, ao mesmo tempo, mantém nos vínculos da sua identidade, o sair de si mesma para percorrer o caminho dialético mediante o qual retorna a essa mesma identidade, agora mediatizada consigo mesma como Espírito Absoluto.

A Ciência da Lógica, vindo a ocupar o lugar da Metafísica antiga, reivindica o título de Metafísica da modernidade tardia. Hegel considerava-se herdeiro da Theologia que coroava a Metafísica greco-cristã. De fato, ele inicia a moderna Filosofia da religião. A dissolução da antiga Theologia significou

\footnotetext{
${ }^{86}$ EF III, FC 55.

${ }^{87}$ GW, 9 p. 18; tr. Br. I pg. 30.
} 
a suprassunção final da transcendência analógica ${ }^{88}$, chave de abóboda do antigo edifício onto-teológico, na imanência do sistema. Para Lima Vaz, dois passos dados por Hegel refletem o destino da nomeação filosófico-teológica cristã de Deus na nossa modernidade pós-metafísica e pós-cristã.

O primeiro diz respeito à inversão operada por ele na hierarquia dos saberes tal como fora estabelecida pelo pensamento clássico. Nesse, a Theologia ou Philosophia Prima, para usar a terminologia de Aristóteles, ocupava o lugar mais alto, a ela estando subordinadas a Física e a Ética. Tomás de Aquino reorganizou profundamente essa hierarquia ao fazer da Teologia revelada a ciência subalternante de todas as outras, a começar pelas ciências filosóficas, estando ela, por sua vez, subalternada à ciência divina comunicada na palavra da revelação. Para Lima Vaz, a inversão hegeliana é uma decorrência inevitável da invalidação do conhecimento analógico do Absoluto, consumada como imanentização do Absoluto no sujeito, ao termo do caminho percorrido pelo próprio sujeito para alcançar o pleno saber de si mesmo ou a perfeita adequação da certeza e da verdade do saber de si mesmo.

O segundo passo na direção da plena transcrição da afirmação de Deus nos quadros conceptuais do sistema e, portanto, da sua captação definitiva na órbita do Eu penso, ou da manifestação do seu mistério na necessidade compreendida do desenvolvimento histórico-dialético do espírito, é dado nas Lições sobre a Filosofia da religião, que ele ministrou em Berlim de 1821 a 1831. A figura da Filosofia da religião surge ao termo desse passo como legítima herdeira da antiga Theologia e, sobretudo, como grandiosa demonstração da identidade entre o conteúdo representado da simbólica cristã e o conteúdo pensado da Filosofia. As Lições sobre Filosofia da religião de Hegel, impelidas pela ambição especulativa que pretende elevá-las à altura da antiga Theologia podem ser consideradas como o campo do mais profundo e decisivo confronto entre a modernidade pós-metafísica e a tradição ocidental da afirmação filosófica de Deus.

$\mathrm{Na}$ terceira jornada filosófica de Lima Vaz, seu pensamento se organiza como um silogismo especulativo no qual a Metafísica é o termo mediador entre a Antropologia Filosófica e a Ética, a saber: AF M E. A afirmação de Deus se enraíza na experiência da relação de transcendência em que se imbricam Antropologia Filosófica, Metafísica e Ética, sendo a Metafísica o ponto de apoio da Antropologia Filosófica e da Ética.

\footnotetext{
${ }^{88}$ A analogia do ser é considerada por importantes autores contemporâneos uma teoria medieval. Ver P. Aubenque, Le Problème de l'être chez Aristote, Paris, PUF, 1962; idem, Les origines de la doctrine de l'analogie de l'être. Sur l'histoire d'un contresens, in Les Études philosophiques (1976), 3-12; A. de Libera, Les sources gréco-arabes de la théorie médiévale de l'analogie de l'être, in Les Études philosophiques:" (1989), 319-345; J.-F. Courtine, Inventio Analogie. Métaphysique et ontothéologie, Paris, Vrin, 2005. O. Boulnois, Metafísicas rebeldes. Gênese e estruturas de uma ciência na Idade Média, São Leopoldo, Editora Unisinos, 2015, p. 152-154.
} 
A modernidade pós-metafísica vê o sol do sistema de razões que a ilumina elevado bem alto sobre seu horizonte histórico. A nomeação filosófica greco-cristã de Deus passa a girar na órbita do sistema, submetida às leis da sua atração e à organização do seu espaço epistemológico. Na idade pós-hegeliana do século XIX, e não por acaso, as Ciências da Religião, ramos da Etnologia, da Antropologia Cultural, da História, da Sociologia, da Psicologia, acabam por constituir-se definitivamente. Elas assinalam a passagem dialético-conceptual da nomeação divina no fato religioso como momento do espírito ou como figura da consciência na Filosofia hegeliana para sua objetivação e descrição simplesmente como fenômeno empírico observável pelas ciências referidas acima.

\section{Algumas Observações}

O programa filosófico tardio de Lima Vaz apresenta suas razões para criticar a inversão noético-metafísica da constituição do em-si inteligível do objeto a partir do Absoluto transcendente. A primazia do ordo cognoscendi consagrado por Descartes reivindica para a reflexão do sujeito humano a origem das coordenadas noéticas que configuram o campo conceitual de novo paradigma filosófico conhecido pelo nome de Metafísica da subjetividade.

A virada antropológica, a virada historiológica e a virada linguística são etapas sucessivas decorrentes da inversão original desencadeada por Duns Scotus. Em todas elas subjaz como desafio maior para a afirmação de Deus, a tese kantiana que "é impossível apontar um critério suficiente e ao mesmo tempo geral da verdade" 89 que conduz, em última análise, à tese de uma pretendida inefabilidade semântica. Hoje em dia, a tese kantiana, remodelada por Frege e por Wittgenstein, transformou-se na tese da inefabilidade da linguagem, o que coloca para o pensamento filosófico sérios interrogativos sobre a relação entre a linguagem e o mundo. A pergunta pelas implicações filosóficas da pretendida inefabilidade da relação linguagem-mundo ainda permanece aberta. Tal como ela vem sendo compreendida hoje em dia, não se trataria de um sucedâneo do dualismo kantiano entre o domínio da experiência, que é cognoscível, e o domínio do númeno, que permanece incognoscível? (cont.)

Endereço do Autor:

Rua Padre Aloysio Sehnem, 186 - Cristo Rei

93022-630 São Leopoldo - RS

aquino@unisinos.br

${ }^{89}$ Crítica da Razão Pura B83. 